\title{
Ras/MAP kinase-dependent and -independent signaling pathways target distinct ternary complex factors
}

\author{
Robert A. Hipskind, ${ }^{1}$ Dirk Büscher, ${ }^{2}$ Alfred Nordheim, ${ }^{1}$ and Manuela Baccarini ${ }^{2-4}$ \\ ${ }^{1}$ Institute for Molecular Biology, Hannover Medical School, Hannover, Germany; ${ }^{2}$ Fraunhofer Institute for Toxicology \\ and Molecular Biology, 30625 Hannover, Germany
}

Transcriptional activation of the immediate early genes c-fos and egr-1 by extracellular signals appears to be mediated by ternary complex factors (TCFs). In BAC-1 macrophages, growth factor stimulation leads to the retardation of protein-DNA complexes containing distinct TCFs. One TCF is recognized by Elk-1 antisera, whereas the other is immunologically related to SAP-1. The appearance and decay of hyperphosphorylated TCF/Elk-1-containing complexes after stimulation coincide with the activation of mitogen-activated protein kinase (MAPK) and the induction and repression of c-fos and egr-1, whereas modified TCF/SAP-1-containing complexes decay more slowly. Suppression of MAPK activation in macrophages and fibroblasts correlates with the failure to induce TCF/Elk-1 hyperphosphorylation without blocking TCF/SAP-1 modification.

Accordingly the modified Elk-1 complex is generated in vitro by activated MAPK, whereas that of SAP-1 is not. Expression of a dominant-negative Ras mutant $\left(\operatorname{Ras}^{\text {Asn17) }}\right)$ in BAC-1 cells does not affect CSF-1-induced TCF/SAP-1 modification while suppressing TCF/Elk-1 phosphorylation. Neither PKC down-regulation by TPA nor inhibition of $G_{i}$ proteins by pertussis toxin pretreatment influences CSF-1-induced signaling to TCFs. These data indicate the existence of two separate signaling pathways for the modification of distinct TCFs: one dependent on Ras and MAPK and converging on TCF/Elk-1, and the other targeting TCF/SAP-1 independently of Ras and MAPK.

[Key Words: Signal transduction; ETS-related proteins; phosphorylation; ras; MAPK]

Received January 27, 1994; revised version accepted June 9, 1994.

Cell growth, survival, and differentiation are mediated by extracellular agents that bind to specific receptors at the cell surface. These receptors, in turn, couple to common intracellular signaling networks that ultimately converge on transcription factor activation and thereby regulate gene expression. In the last few years, some of the components of these cytosolic signal transduction pathways have been identified, and many have been shown to be encoded by cellular proto-oncogenes, like c-ras, c-src, or c-raf. However, neither the precise nature of the interactions among cytosolic signal transducers nor the identity of their nuclear targets is yet fully defined.

The serum response element (SRE) is a regulatory element mediating the induction of several immediate early (IE) genes, such as the c-fos proto-oncogene. Genomic footprinting has shown that the c-fos SRE is continuously occupied in vivo throughout growth factor induction (Herrera et al. 1989; König 1991). The pattern of DNA-protein interaction at the SRE can be reproduced

\footnotetext{
${ }^{3}$ Corresponding author.

${ }^{4}$ Present address: Vienna Biocenter, Institute for Cell and Microbiology, A-1030 Vienna, Austria.
}

in vitro by binding of a serum response factor (SRF) dimer (Treisman 1986; Norman et al. 1988; Schröter et al. 1990) and one molecule of an accessory protein called ternary complex factor (TCF) (Shaw et al. 1989). The abilities to dimerize, bind DNA, and interact with TCF map to a subdomain of SRF spanning residues 133-222 (Norman et al. 1988; Mueller and Nordheim 1991).

Two cloned, ETS domain-containing proteins, Elk-1 and SAP-1, have been identified as ternary complex factors (Hipskind et al. 1991; Dalton and Treisman 1992). TCFs require SRF or the core subdomain of SRF to bind to the SRE (Shaw et al. 1989) but can bind directly to purine-rich DNA motifs, like the Drosophila E74 ETSprotein recognition sequence (Janknecht and Nordheim 1992; Rao and Reddy 1992). For both Elk-1 and SAP-1, DNA binding is mediated by an ETS domain located at the amino terminus of the protein. The formation of ternary complexes additionally depends upon Elk-1/SAP-1 homology domain B. A third shared domain, the carboxy-terminal C-box, contains several conserved mitogen-activated protein kinase (MAPK) phosphorylation sites and is therefore an attractive candidate as an acceptor of signals generated in response to growth factor stimulation (Dalton and Treisman 1992; for review, see 
Treisman 1994|. In support of this hypothesis, TCF and Elk-1 can be phosphorylated in vitro by MAPK and by a 42-kD growth factor-regulated kinase (Gille et al. 1992; Janknecht et al. 1993; Marais et al. 1993). Mitogen stimulation of cells transfected with a fusion protein containing the Elk-1 C-box leads to Elk carboxy-terminal phosphorylation in a manner partially reproduced by MAPK in vitro (Marais et al. 1993). Similarly, epidermal growth factor (EGF) and serum induction in vivo cause an increased phosphorylation of endogenous TCF that shows a tight correlation to $\mathrm{c}$-fos promoter activity (Zinck et al. 1993; Hipskind et al. 1994). Consistent with a link between TCF/Elk-1 phosphorylation and c-fos induction, mutations of the MAPK phosphorylation sites in the C-box of Elk-1-GAL4 fusion proteins (Janknecht et al. 1993; Marais et al. 1993), of Elk-1 itself (Janknecht et al. 1993\}, or of Elk-1 mutants with altered binding specificity (Hill et al. 1993) significantly reduce their ability to mediate trans-activation. Growth factor-mediated modification of other TCFs, such as SAP-1, has not been reported, and the role they play in mediating induction is still not clear.

We were interested in dissecting the signal transduction pathways lying upstream of c-fos induction and particularly in determining which cytosolic kinases may act as TCF regulators in vivo. Our model system is a macrophage cell line, BAC-1.2F5 (Morgan et al. 1987), that strictly depends on colony stimulating factor-1 (CSF-1) for survival and proliferation (for review, see Baccarini and Stanley 1990). The cell-surface receptor for CSF-1 (CSF-1R) is a tyrosine kinase encoded by the c-fms protooncogene (Sherr et al. 1985). Like most tyrosine kinase as well as nontyrosine kinase receptors, the CSF-1R is linked to an intracellular signaling network that involves a functional $\mathrm{p} 21^{\mathrm{ras}}$. Microinjection of anti-Ras antibodies suppresses the proliferative response to CSF-1 (Smith et al. 1986), as does the overexpression of the GTPase-activating protein (GAP) catalytic domain (Bortner et al. 1991).

The product of the proto-oncogene c-raf (for review, see Rapp 1991/ has also been identified as an important intermediate in the transduction of the CSF-1 mitogenic signal (Baccarini et al. 1990; Büscher et al. 1993). The exact mechanism by which RAF-1 is phosphorylated and activated in response to growth factor stimulation is still unknown, although $\mathrm{p} 21^{\text {ras }}$ has recently been implicated in this process (Troppmair et al. 1992; Moodie et al. 1993; van Aelst et al. 1993; Vojtek et al. 1993; Warne et al. 1993; Zhang et al. 1993). $\mathrm{p} 21^{\text {ras }}$ also plays a key role in the phosphorylation and activation of MAPKs (also known as ERKs or extracellular signal regulated kinases) and the $85-$ to $9 \overline{2}-\mathrm{kD}$ ribosomal $\mathrm{S} 6$ kinases (RSK $\overline{\text { ) }}$ (deVries-Smits et al. 1992; Thomas et al. 1992; Wood et al. 1992; Moodie et al. 1993). This may be mediated via RAF and MEK-1 (MAPK or ERK kinase) because activated RAF-1 phosphorylates $\bar{M} E K-\overline{1}$ in vitro (Dent et al. 1992; Howe et al. 1992; Kyriakis et al. 1992; LangeCarter et al. 1993). In vivo the MEK-1/MAPK signaling pathway is activated in v-raf-infected NIH-3T3 cells (Dent et al. 1992; Howe et al. 1992; Kyriakis et al. 1992) and in COS- 1 cells transiently transfected with activated RAF (Howe et al. 1992). These observations support the following potential signaling order: Ras $\rightarrow \mathrm{RAF} \rightarrow$ MEK$1 \rightarrow$ MAPK.

This scheme may represent an oversimplification, as v-raf-mediated activation of the MAPK pathway has been shown to be a function of the cellular context (Gallego et al. 1992; Gupta et al. 1992; Wood et al. 1992; Samuels et al. 1993). In addition, a RAF-independent MEK-1 kinase (MEKK) has recently been cloned and shows high homology to the yeast MEK regulators Byr2 and Stell (Lange-Carter et al. 1993). This indicates the existence of additional, RAF-independent MAPK regulatory pathways.

We show in this paper that growth factor-induced activation of ERK-1 and ERK-2 correlated temporally with the hyperphosphorylation of a distinct TCF activity immunologically related to Elk-1 (TCF/Elk-1). A second activity (TCF/SAP-1), recognized by an antiserum specific for SAP-1, was also rapidly modified upon stimulation. v-raf expression in BAC-1 cells suppressed CSF-1-induced ERK-1 and ERK-2 activation and TCF/Elk-1 modification. Accordingly, c-fos induction was attenuated in these cells. Decreased ERK-1 and ERK-2 activity correlated with diminished TCF/Elk-1 phosphorylation in EGF-stimulated fibroblasts carrying a kinase-negative human EGF receptor and in serum-stimulated NIH-3T3 cells. In contrast, modified TCF/SAP-1 complexes can be detected in the absence of MAPK activation in the systems examined. Consistent with this, the mobility of ternary complexes formed with in vitro-translated SAP-1 was not modified by purified active ERK-2, whereas that of Elk-1-containing complexes was. Furthermore, inducible expression of a dominant-negative Ras construct blocked TCF/Elk-1, but not TCF/SAP-1 modification, indicating that diverging signaling pathways lead to the modification of TCF/Elk-1 and TCF/SAP-1.

\section{Results}

CSF-1 stimulation causes the appearance of TCF complexes with decreased mobility

We used a mouse macrophage cell line to investigate whether growth factors induce changes in TCF corresponding to gene activation in myeloid cells. Growth factor-starved BAC-1 cells were stimulated with CSF-1, whole-cell extracts were prepared at different times after stimulation and TCF was analyzed by ternary complex formation. The binding reactions contained a ${ }^{32} \mathrm{P}$-labeled c-fos SRE probe and core $\mathrm{SRF}_{90-244}$, which encompasses the domains necessary for DNA binding and interaction with TCF (Norman et al. 1989; Mueller and Nordheim 1991). Changes in the mobility of core SRF-directed ternary complexes reflect the modification state of TCF (Zinck et al. 1993; Marais et al 1993), which in turn correlates with the activity of the c-fos promoter (Zinck et al. 1993; Hipskind et al. 1994).

In extracts prepared from CSF-1-starved cells, the core 
A
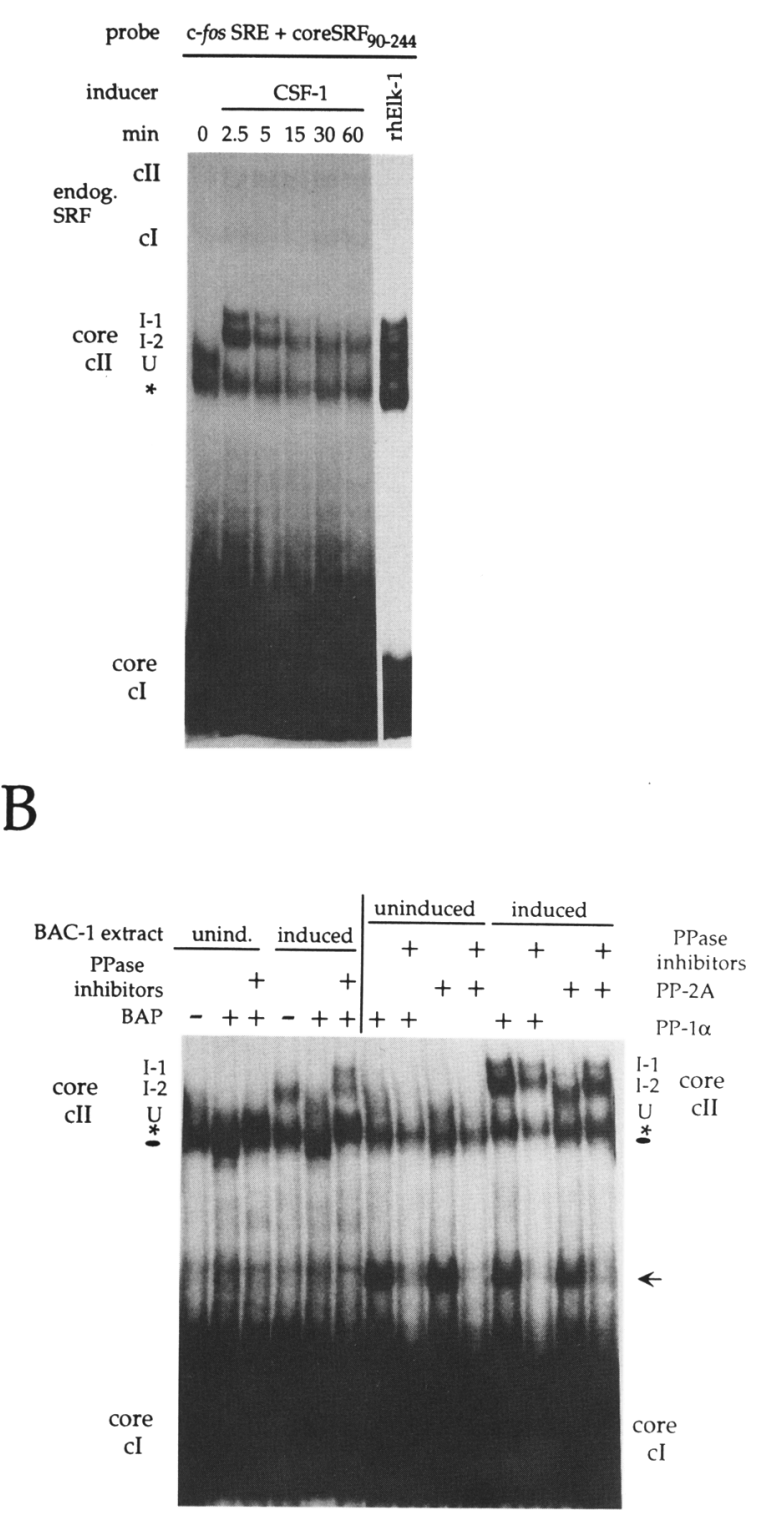

SRF-assisted ternary complexes (core cII) appeared as two bands (Fig. 1A), the lower of which $\left(^{*}\right)$ was not detectably altered by factor stimulation. Induction with CSF-1 caused the disappearance of the upper uninduced band (U) and the appearance of two slower ternary complexes 2.5 min after CSF-1 stimulation (Fig. 1A). For this reason these slower complexes will subsequently be called inducible. The upper inducible complex (I-1) rapidly declined after induction, whereas the lower inducible complex (I-2) could be detected much later. Without core SRF, ternary complexes (cII) were formed on the SRE probe with endogenous SRF by both uninduced and induced extracts, whereas no complexes appeared at the core $\mathrm{cI}$ and core cII positions (Fig. 1A; data not shown). All complexes were supershifted upon the addition of an
Figure 1. CSF-1 stimulation causes phosphatase-sensitive changes in the mobility of TCF-DNA complexes that correlate with IE gene activation. (A) Mobility-shift analysis of complexes formed by whole-cell extracts from resting BAC-1 cells $(0)$ or from cells stimulated with recombinant CSF-1 for the indicated times. The control reaction contained recombinant human Elk-1 (rhElk-1). The probe was a ${ }^{32}$ P-labeled c-fos SRE. Reactions were supplemented with core $\mathrm{SRF}_{90-244}$, that spans SRF residues $90-244$. The rhElk-1 lane (right) comes from a shorter exposure of the same gel. We note that the rhElk-1 complexes do not comigrate exactly with either I-1 or I-2. (core cI) Core SRF dimer; (core cII) ternary complexes; $\left(^{*}\right)$ uninducible ternary complex; $(\mathrm{U})$ uninduced ternary complexes; $(\mathrm{I}-1, \mathrm{I}-2)$ induced ternary complexes; (cI) endogenous SRF dimers; (cII) ternary complexes formed with endogenous SRF. $(B)$ Both induced and uninduced complexes are affected by phosphatase digestion. Whole-cell extracts from either unstimulated or CSF-1-stimulated (2.5 min) BAC-1 cells were dialyzed as described in Materials and methods to remove phosphatase inhibitors. An aliquot of the dialyzed extract was assayed with the c-fos SRE and core $\mathrm{SRF}_{90-244}$ as described in $A$. Mobility-shift analysis after treatment with bacterial alkaline phosphatase (BAP), purified PP-l $\alpha$, and purified PP-2A are shown. A phosphatase inhibitor mix (see Materials and methods) was added where indicated to block phosphatase activity and control for nonspecific effects of incubation. The lanes come from different regions of the same gel, and those marked - contain the dialyzed extract incubated without phosphatases in the absence of inhibitors. Please note that under these conditions complex I-1 is lost in the BAP reaction buffer containing $\mathrm{MgCl}_{2}$, whereas it remains in the PP- $1 \alpha$ reaction buffer that lacks this ion. The arrow designates a novel complex of unknown identity generated by purified PP-1 $\alpha$ and PP-2A in both uninduced and induced extracts.

antiserum specific for both core SRF and SRF (data not shown; Hipskind et al. 1991). Recombinant human Elk-1 (rhElk-1), obtained by overexpression in continuously growing HeLa cells (Janknecht and Nordheim 1992), formed a series of core cII complexes migrating in the same region of the gel (Fig. 1A), and similar complexes were also found in nuclear extracts of BAC-1 cells /data not shown).

Slower migrating direct and ternary complexes have been shown to arise from an induction-dependent phosphorylation of TCF and Elk-1 (Hill et al. 1993; Janknecht et al. 1993; Marais et al. 1993; Zinck et al. 1993) and correlate with highly phosphorylated species of TCF in two-dimensional gels (Zinck et al. 1993). If this is the case in mouse whole-cell extracts, then phosphatase treatment should chase the induced complexes back to the uninduced position. We therefore dialyzed the mouse whole-cell extracts and incubated them with different phosphatases. Both induced complexes disappeared upon incubation with bacterial alkaline phosphatase (BAP). Concomitantly, a complex with an electrophoretic mobility similar to complex $U$ became visible. Furthermore, a second complex (marked with a black oval) with an electrophoretic mobility faster than the uninducible complex $\left(^{*}\right)$ was observed, which was also detectable in BAP-treated uninduced extracts. Interestingly complex I-1, but not I-2, was diminished in the 
mock incubation for BAP, suggesting the presence of an endogenous phosphatase specifically affecting $\mathrm{I}-1$. This activity required $\mathrm{Mg}^{2+}$, because it was active in the $\mathrm{MgCl}_{2}$-containing buffer used for the BAP reaction but not in the PP-1 $\alpha$ buffer lacking this ion. Both the putative endogenous phosphatase and BAP were blocked by phosphatase inhibitors. Treatment with the serine/threonine-specific phosphatases PP- $1 \alpha$ and PP-2A had little effect on the core cII ternary complexes in the uninduced extracts. In induced extracts, only PP-2A affected the induced complexes, causing their faster migration. This effect was blocked by phosphatase inhibitors (Fig. 1B, right). The activity of both PP- $1 \alpha$ and PP-2A was indicated by the appearance of a new complex of unknown identity in the extracts (arrow, Fig. 1B, right). Thus, the induced complexes were phosphatase sensitive, although we have not been able to establish a clear precursor-product relationship between the uninduced and induced complexes.

\section{I-1 contains an Elk-1-related TCF, and the TCF in $I-2$ is immunologically related to SAP-1}

TCFs have been shown to generate core SRF/SRE and wild-type SRF/SRE ternary complexes, as well as direct complexes with the Drosophila E74-binding sites. Similarly the BAC-1 whole-cell extracts formed a series of complexes with the E74 probe, some of which disappeared upon induction, along with the appearance of two slower migrating complexes (data not shown). To confirm the interrelationship of the direct and core SRF ter- nary complexes formed in the BAC-1 extracts, we added cold E74-binding site to the ternary complex reactions. A progressive increase in the concentration of this competitor prevented the appearance of the core cII complexes (Fig. 2A). This competition was specific, because a mutant E74 sequence incapable of forming direct complexes had no effect, even at a 2000 -fold molar excess, and neither oligonucleotide affected the formation of the core SRF binary cI complexes (Fig. 2A). This indicates that the proteins forming ternary complexes with core SRF and the SRE also bind directly and specifically to the E74 ETS-protein recognition sequence.

In addition, neither uninduced nor induced ternary complexes were formed on a probe containing a mutation in the DNA sequence upstream of the SRF-binding site (data not shown) necessary for TCF binding in vitro and activation of reporter constructs in vivo (Shaw et al. 1989; Graham and Gilman 1991; Shaw 1992). Furthermore, BAC-1 whole-cell extracts were capable, like human TCF (Mueller and Nordheim 1991; Hipskind et al. 1991), of forming ternary complexes on the SRE with core MCM1. This yeast transcription factor is homologous to SRF in its DNA-binding domain and is implicated in the pheromone signaling pathway in Saccharomyces cerevisiae. The induced and uniduced complexes formed with core MCM1 resembled those formed with core SRF (data not shown). Thus, the core cII complexes contain bona fide TCFs.

In human cells the major TCF activity is indistinguishable from Elk-1 (Hipskind et al. 1991; Zinck et al. 1993; R. Hipskind, unpubl.). In BAC-1 extracts, an Elk-
A

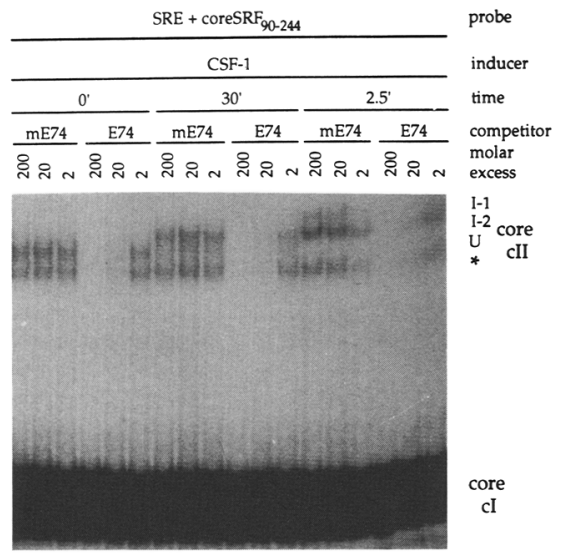

B

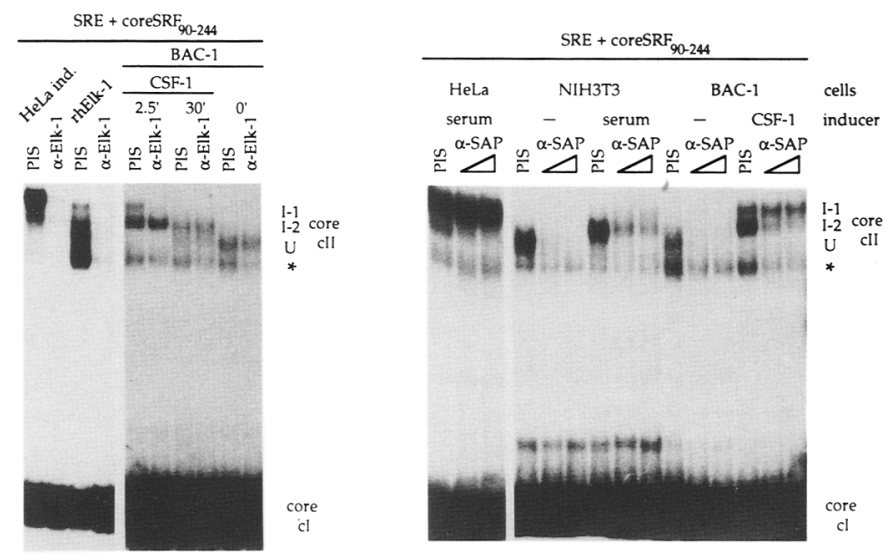

Figure 2. Characterization of TCF activity in BAC-1 whole-cell extracts. $(A)$ Ternary complex formation on the SRE is inhibited by the E74 ETS-binding sequence. Mobility-shift analysis of ternary complexes formed by extracts of CSF-1 stimulated cells in the presence of the indicated molar excess of either unlabeled E74 oligonucleotide or a mutated derivative incapable of binding TCF or Elk-1. (B) Immunological characterization of I-1 and I-2. (Left) I-1, but not I-2, reacts with an anti-Elk-1 serum. Binding reactions contained whole-cell extracts from serum-induced HeLa cells, rhElk-1, or whole-cell extracts from uninduced and CSF-1-stimulated BAC-1.2F5 cells, along with ${ }^{32} \mathrm{P}$-labeled $\mathrm{c}-\mathrm{fos}$ SRE and core $\mathrm{SRF}_{90-244}$. They were supplemented with either an anti-Elk-1 serum ( $\alpha$-Elk-1) or with preimmune serum (PIS). The HeLa and rhElk-1 lanes come from a shorter autoradiographic exposure of the same gel. (Right) I-2 contains a protein immunologically related to SAP-1. Whole-cell extracts were prepared from the cells indicated, either prior to induction or after stimulation with the factor shown above the lanes. Nonimmune serum $(0.5 \mu l)$, or $1 \mu l$ of a SAP-1-specific rabbit serum was added before the extract. Reactions were performed as described in the legend to Fig. 1. 
1-related mRNA could be readily detected with a human Elk-1 probe (data not shown). We therefore tested whether any of the ternary complexes formed by these mouse macrophage cells contained Elk-1-related proteins by adding anti-Elk-1 antiserum to the binding reactions (Hipskind et al. 1991). Preimmune serum did not influence TCF binding (Fig. 2B, left). In contrast, the anti-Elk serum significantly reduced a subset of the ternary complexes formed by the BAC-1 extracts. In the uninduced extract $(0 \mathrm{~min})$, the amount of the complex marked with an asterisk $\left({ }^{\star}\right)$ was lowered, and the uninduced complex (U) was slightly affected. After induction (2.5 min), the upper inducible complex I-1 was virtually eliminated by the Elk-1 antiserum, whereas the other inducible complex (I-2) was insensitive to this treatment. The same amount of serum significantly decreased the formation of ternary complexes by rhElk-1 and whole-cell extracts prepared from serum-induced HeLa cells. Two other Elk-1 antisera, directed against the ETS domain (amino acids 1-83) and the carboxyterminal 120 amino acids (Zinck et al. 1993), also block these ternary complexes (data not shown).

Three separate Elk-1-specific antisera did not react with the I-2 complexes, indicating that they contain a TCF distinct from Elk-1. Because Northern analyses indicated the presence of mRNA hybridizing to a human SAP-1 probe (data not shown), we wondered whether these complexes might contain SAP or a related protein. To determine this, we used an antiserum that specifically immunoprecipitates SAP-1 but not Elk-1 or SAP-2 (A. Rogers, S. Dalton, and R. Treisman, unpubl.). This serum eliminated almost all of the uninduced $(U)$ and some of the uninducible $\left(^{\star}\right.$ ) complex (Fig. 2B, right, NIH$3 \mathrm{~T} 3$ and $\mathrm{BAC}-1)$ and blocked most of the lower induced complex I-2 (BAC-1 induced lanes). Interestingly, seruminduced NIH-3T3 cells contained mainly I-2 complexes. On the contrary, human cell lines contained much more I-1 than I-2 activity, and the I-2 complex was also sensitive to the SAP-1 antiserum (Fig. 2B, HeLa lanes; R. Hipskind and $M$. Baccarini, unpubl.). Because the $U$ and I-2 complexes both reacted with the SAP-1 antiserum, I-2 might arise from induction-dependent modification of the TCFs forming complex U. As expected, the SAP-1 antiserum did not affect the upper inducible complex I-1 recognized by the Elk-1 antisera. The complementary pattern of inhibition observed with the Elk-1 and SAP-1 antisera indicates that the induced complexes contain distinct TCFs. Because of their reactivity with these antisera, the factors forming complexes I-1 and I-2 will be referred to as TCF/Elk-1 and TCF/SAP-1, respectively.

As described above, both TCF/Elk-1- and TCF/SAP-1containing complexes were phosphatase sensitive. To obtain direct evidence of growth factor-induced phosphorylation of TCF/Elk-1 and TCF/SAP-1, we labeled BAC-1 cells in vivo with ${ }^{32} \mathrm{P}$-labeled orthophosphate. Immunoprecipitation with the Elk-1 ETS domain-specific antiserum and the SAP-1-specific serum yielded phosphorylated bands with apparent molecular masses of 75 and $52 \mathrm{kD}$, respectively (data not shown). CSF-1 induction led to a 2.2 -fold increase in the phosphoryla- tion of the $75-\mathrm{kD}$ band (uninduced, $4390 \mathrm{cpm}$ Cerenkov; induced, $9595 \mathrm{cpm}$ Cerenkov) and to a 1.75-fold increase in the phosphorylation of the $52-\mathrm{kD}$ band (uninduced, $1115 \mathrm{cpm}$ Cerenkov; induced, $1925 \mathrm{cpm}$ Cerenkov). Tryptic phosphopeptide maps of TCF/Elk-1 were very similar to those of overexpressed recombinant human Elk-1 (Janknecht et al. 1993) and clearly differed from the tryptic phosphopeptide pattern of TCF/SAP-1 (data not shown). Thus, the antibodies reacting specifically with both uninduced and induced ternary complexes formed by BAC-1 whole-cell extacts recognize distinct phosphoproteins whose degree of phosphorylation is affected by growth factor induction.

\section{The kinetics of growth factor-induced activation of MAPKs correlate with TCF/Elk-1 modification and gene induction}

The kinetics of MAPK activation following induction of BAC-1 cells with either CSF-1 or lipopolysaccharide (LPS) were investigated by an in-gel kinase assay (Chao et al. 1992). This technique allowed us to measure MAPK activity in the same whole-cell extracts used for the DNA-binding experiments. The extracts were resolved by SDS-PAGE in a gel containing myelin basic protein (MBP). After renaturation, the activities of ERK-1 and ERK-2, as well as other MBP kinases, were visualized by the transfer of radioactive phosphate to MBP. The two phosphorylated bands comigrate with proteins reacting with a MAPK-specific antiserum, as shown by Western blotting; furthermore, activation measured in the MAPK assay strictly correlated with tyrosine phosphorylation of immunoprecipitated ERK2 (data not shown|. Lysates of CSF-1-starved BAC-1 did not contain active ERK-1 or ERK-2. CSF-1 induction led to a very rapid activation of these kinases that subsequently declined but did not disappear completely (Fig. 3A, BAC-1). The kinetics of ERK-1 and ERK-2 activation correlate well with the appearance of the induced ternary complexes (Fig. 1A). Equivalent amounts of ERK-1 and ERK-2 were present at each time point, as measured by immunoblotting (data not shown).

To test whether the kinetics of MAPK and TCF/Elk-1 activation and repression correlate with the induction of SRE-driven genes, we isolated RNA from whole-cell extracts and hybridized slot blots with c-fos, egr-1 and GAPDH probes, followed by densitometric quantitation (Table 1). As expected, the induction and repression kinetics of c-fos and egr-1 lagged just behind those of MAPK activation and TCF/Elk-1 modification (Tables 1 and 2; data not shown). As noted above, TCF/SAP-1 also appears with rapid kinetics, but its decay does not correspond with promoter or MAPK inactivation.

\section{Decreased MAPK activation correlates with a lack of TCF/Elk-1 but not of TCF/SAP-1 modification in mouse macrophages and fibroblasts}

Constitutive v-raf expression in BAC-1 cells relieves their dependence on CSF-1 and leads to autonomous 
B
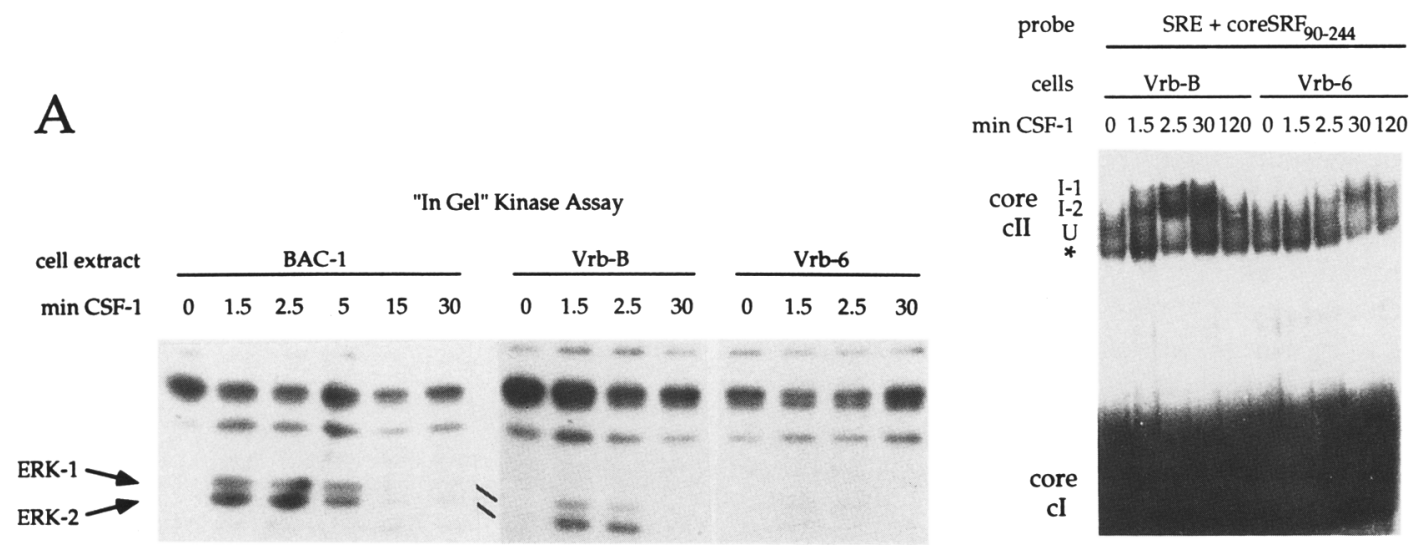

Figure 3. MAPK activation and I-1 formation are impaired in v-raf-expressing BAC-1 cells. $(A)$ In-gel kinase assay of MAPK activity in whole-cell extracts from CSF-1-stimulated BAC-1.2F5, Vrb-B, and Vrb-6 cells. Cells were either left untreated $(0)$ or incubated with CSF-1 $\left(6.3 \mathrm{nM}\right.$ at $\left.37^{\circ} \mathrm{C}\right)$ for the indicated times. Vrb-B and Vrb-6 cell lines are growth factor-independent cell lines derived from BAC-1.2F5 cells after infection with a v-raf retrovirus. In each lane, $7.5 \mu \mathrm{g}$ of protein from whole-cell extracts was loaded. The separating gel contained $0.2 \mathrm{mg} / \mathrm{ml}$ of MBP. Arrows indicate the positions of ERK-1 and ERK-2. $(B)$ Mobility-shift analysis of complexes formed by whole-cell extract from resting and CSF-1-stimulated Vrb-B and Vrb-6 cells. Cells were either left untreated (0) or stimulated with CSF-1 $\left(6.3 \mathrm{nM}\right.$ at $\left.37^{\circ} \mathrm{C}\right)$ for the indicated times. Reactions contained ${ }^{32} \mathrm{P}$-labeled c-fos SRE and core SRF ${ }_{90-244}$. The designation of the complexes is described in the legend to Fig. 1A.

growth in the absence of autocrine growth factor production (Büscher et al. 1993). We investigated two CSF-1independent clones derived from BAC-1 cells, Vrb-B and Vrb-6, that were obtained in two independent infections with v-raf retroviral vectors. The level of expression of the v-raf protein is twofold (Vrb-B) or fivefold (Vrb-6) that of the endogenous RAF-1 product (Büscher et al. 1993). v-raf expression in the BAC-1 cell background did not cause constitutive ERK-1 and ERK-2 activation; on the contrary, CSF-1 stimulation resulted in a slightly reduced MAPK activation in Vrb-B cells relative to BAC-1, whereas in the Vrb- 6 clone little if any activation of ERKs was detectable (Büscher et al. 1993; Fig. 3A, Vrb-B, Vrb-6). Western blots showed comparable amounts of MAPK protein in all instances (data not shown). Thus, suppression of ERK-1 and ERK-2 activation correlated with the amount of v-raf expressed by the clones.

We used these clones to determine the effect of impaired MAPK activation on the appearance of the in-

Table 1. Relative IEG induction in BAC-1 cells

\begin{tabular}{lcccccc}
\hline & & \multicolumn{5}{c}{ Time (min) } \\
\cline { 3 - 7 } Probe & Inducer & 2.5 & 5 & 15 & 30 & 60 \\
\hline c-fos & CSF-1 & 0.8 & 0.9 & 23 & 8.9 & 2.0 \\
egr-1 & CSF-1 & 1.0 & 0.7 & 23 & 19 & 6.1 \\
\hline
\end{tabular}

RNA $(2.5 \mu \mathrm{g})$ isolated from whole cell extracts was slot-blotted onto nylon and hybridized sequentially with c-fos, egr-1, and GAPDH probes. The 0 -min time point was taken as 1.0 arbitrary units. Essentially identical values were obtained in two separate measurements. duced ternary complexes. Analysis of ternary complex formation (Fig. 3B) showed that whole-cell extracts from CSF-1-starved Vrb-B and Vrb-6 cells formed uninduced core cIl complexes, consistent with the fact that MAPK is not activated by v-raf expression in these cells. Upon CSF-1 induction, complex I-2, containing modified TCF/ SAP-1, still appears in Vrb-6 extracts, albeit in reduced amounts (Fig. 3B). A much stronger reduction has occurred in complex I-1, which is barely visible. Thus, little TCF/Elk-1 hyperphosphorylation is detectable when MAPK activation has been strongly suppressed. In Vrb-B cells, ERK-1 and ERK-2 activation was only partially impaired, and the amounts of inducible complexes I- 1 and $\mathrm{I}-2$ were comparable to those detected in BAC-1 extracts after CSF-1 (Fig. 3B).

Consistently, quantitation of Northern blots showed that induction of c-fos and egr-1 mRNA by CSF-1 was strongly attenuated in Vrb- 6 cells, whereas it was only slightly reduced in Vrb-B cells (Table 2; Büscher et al.

Table 2. Relative c-fos induction after CSF-1 stimulation

\begin{tabular}{lccc}
\hline & \multicolumn{3}{c}{ Time $(\mathrm{min})$} \\
\cline { 2 - 4 } Cells & 0 & 30 & 90 \\
\hline BAC-1 & 1.0 & 84 & 0.9 \\
Vrb-B & 3.7 & 69 & 1.0 \\
Vrb-6 & 2.5 & 27 & 0.9 \\
\hline
\end{tabular}

Total RNA (10 $\mu \mathrm{g})$ isolated from whole cell extracts was analyzed by Northern blotting with a c-fos and GAPDH probe. The values are presented relative to the BAC-1 0 -min time point. Two separate Northern analyses yielded similar results. 
1993). The degree of attenuation corresponded to the amount of v-raf protein expressed and to the degree of impairment of MAPK activation and TCF/Elk-1 modification. This attenuation of IEG activation has been observed in 12 separate $\mathrm{v}$-raf-expressing BAC clones, as well as in v-raf-transformed fibroblasts (Büscher et al. 1993; Yu et al. 1993).

To test whether the strong correlation between MAPK activation and TCF/Elk-1 modification described above was restricted to cells of the macrophage lineage, we used two different mouse fibroblast cell lines, B82L cells expressing human EGF receptor (hEGFR) mutants and NIH-3T3. In the B82L cells, EGF stimulation caused MAPK activation by the wild-type hEGFR and by the carboxy-terminal truncated hEGFR mutant C973 (Fig. 4A). This mutant lacks all of the autophosphorylation sites and does not undergo internalization but actively transduces EGF mitogenic signals (Chen et al. 1988). In contrast, stimulation of a kinase-negative receptor (M721; Chen et al. 1988) led to dramatically reduced MAPK activation (Campos-González and Glenney 1992; Selva et al. 1993). This mutant is also incapable of activating RAF-1 (Baccarini et al. 1991). Surprisingly, MAPK activation following serum induction of NIH-3T3 cells was extremely poor relative to the wild-type and C973B82L cells or to stimulated BAC-1 cells (Fig. 3A). The level of MAPK activation observed in serum-induced NIH-3T3 cells was similar to that detected in EGF-induced M721-B82L cells (Fig. 4A). The $\alpha$-MAPK Western blot shows that all of the cell lines contained comparable amounts of ERK-1 and ERK-2 (Fig. 4A).

These same extracts were tested for core SRF-directed ternary complex formation. I-1 (TCF/Elk-1) was barely induced in both NIH-3T3 and M721 cells, whereas it was readily formed in extracts from cells activating MAPK upon stimulation (Fig. 4B). This complex is sensitive to the Elk-1-specific antiserum (data not shown). In contrast to I-1, I-2 appeared upon induction irrespective of whether or not MAPK is activated (Fig. 4B). In all these extracts, I-2 formation was blocked by the SAP-1 antiserum (Fig. 2B; data not shown), indicating that in both myeloid and fibroblastic cells a SAP-1-related TCF is modified upon induction.

\section{MAPK alters the mobility of Elk-1-but not $S A P$-1-containing ternary complexes}

Our results, as well as those from other groups /Gille et al. 1992; Hill et al. 1993; Janknecht et al. 1993; Marais et al. 1993), suggested that Elk-1 is in the MAPK signaling pathway and is a substrate for MAPK. In contrast, TCF/ SAP-1 phosphorylation can still occur when MAPK activation is impaired. To directly test the effect of MAPK on the two TCFs, human Elk-1 and SAP-la prepared by coupled in vitro transcription/translation (IVT) were incubated with activated ERK-2 in the presence of $\mathrm{MgCl}_{2}$ and $\left[\gamma^{-32} \mathrm{P}\right] \mathrm{ATP}$, subjected to immunoprecipitation with the respective antisera, and analyzed by SDS-PAGE followed by autoradiography.

An ERK-2-dependent phosphorylation of IVT Elk-1 and IVT SAP-1a was detectable in SDS-PAGE (Fig. 5, left). The addition of ERK-2 also led to the $\mathrm{Mg}^{2+}$ - and ATP-dependent appearance of slower migrating IVT Elk1-containing ternary complexes that comigrate with mouse- and human-induced ternary complex I-1 (Fig. 5, right). On the other hand, IVT SAP-1 formed two SRFassisted complexes that did not comigrate with complex I-2 and were hardly affected by ERK-2 treatment (Fig. 5,
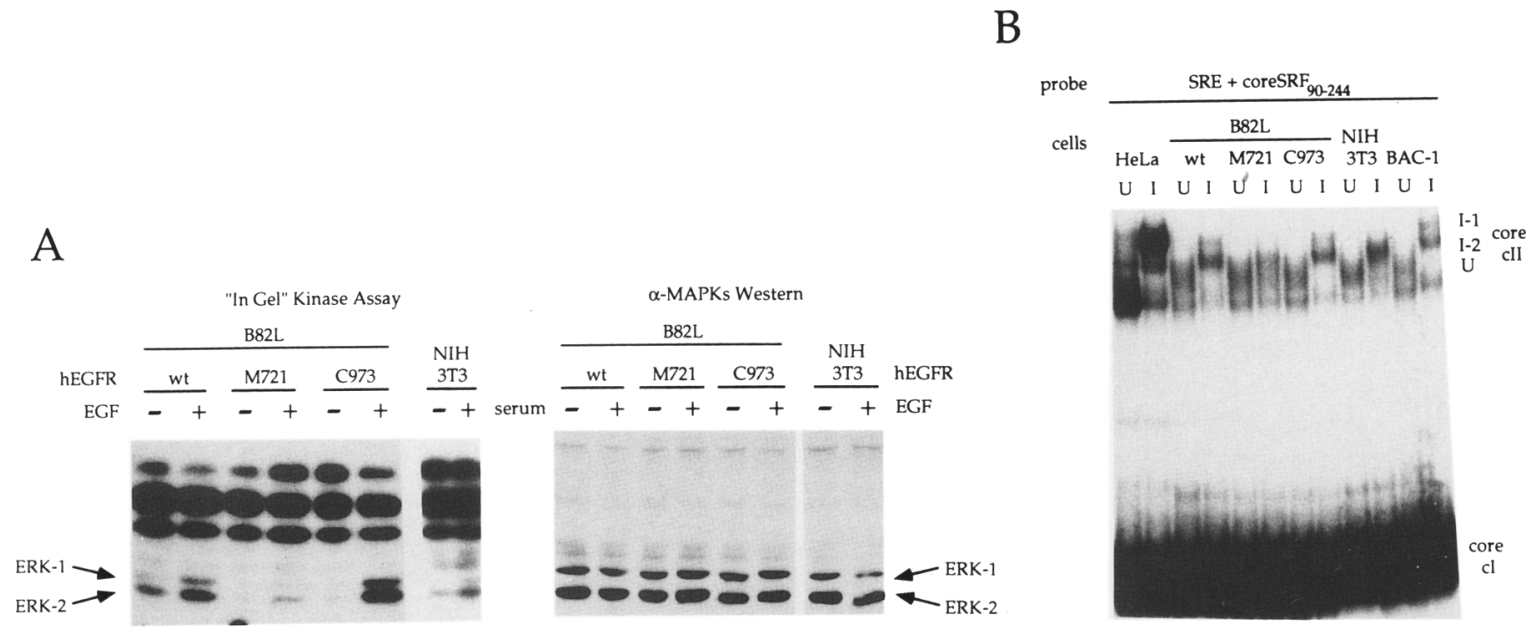

Figure 4. MAPK activation and TCF modification in resting or induced mouse fibroblasts. $|A|$ In-gel kinase assay of MAPK activity in whole-cell extracts from B82L and NIH-3T3 cells. B82L cells expressing wild-type hEGFR (wt), a kinase negative mutant (M721), and a carboxy-terminal truncation (C973) were either left untreated (-) or incubated with EGF $\left[100 \mathrm{nM}\right.$ for $5 \mathrm{~min}$ at $\left.37^{\circ} \mathrm{C}(+)\right]$. NIH-3T3 cells were either left untreated $(-)$ or induced with $10 \% \mathrm{FCS}\left[7.5 \mathrm{~min}, 37^{\circ} \mathrm{C}(+)\right]$. In each lane, $15 \mu \mathrm{g}$ of protein from whole-cell extracts was loaded. MBP $(0.2 \mathrm{mg} / \mathrm{ml})$ was polymerized in the separating gel. Arrows indicate the position of ERK-l and ERK-2. (B) Mobilityshift analysis of various whole-cell extracts. Reactions contained ${ }^{32}$ P-labeled c-fos SRE and core SRF ${ }_{90-244}$ as described in the legend to Fig.1A. 
Figure 5. ERK-2 treatment of in vitrotranslated human Elk-1 and SAP-la. Human Elk-1 and SAP-la were generated by coupled IVT. (Left) In vitro phosphorylation of Elk-1 and SAP-1 by activated ERK2. Equal amounts of IVT ${ }^{35} \mathrm{~S}$-labeled proteins were incubated with $\mathrm{MgCl}_{2}$ and $\left[\gamma^{-32} \mathrm{P}\right]$ ATP in the absence or presence of activated ERK-2, as indicated above the lanes. After immunoprecipitation, proteins were analyzed by $10 \%$ SDS-PAGE. The gel was exposed to two films. Only the second film, documenting ${ }^{32} \mathrm{P}$ incorporation in the presence or absence of activated ERK-2, is shown. Size standards are shown at left as kilodaltons. (Right) Mobility-shift analysis of in vitro-phosphorylated proteins. Kinase reactions were assembled (with cold ATP) as shown above the lanes, with cold IVT proteins. Aliquots were then used in mobility-shift reactions containing ${ }^{32} \mathrm{P}-\mathrm{la}$ beled c-fos SRE and core $\mathrm{SRF}_{90-244}$.

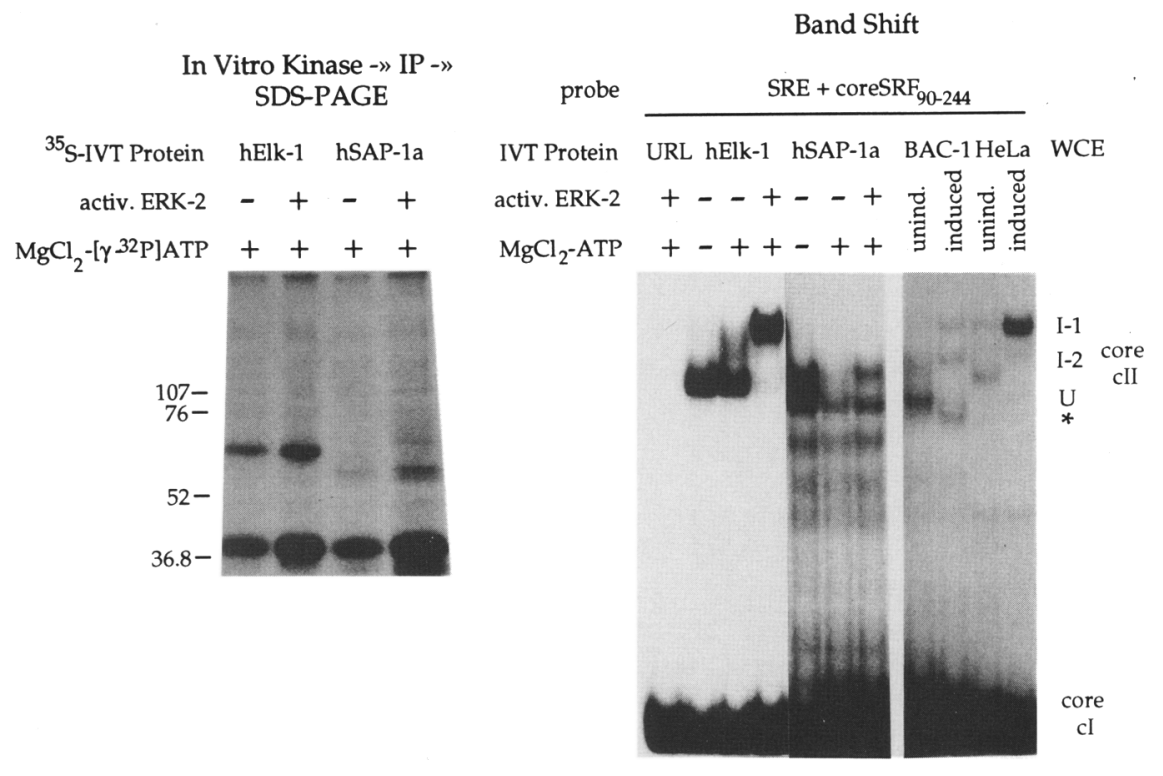

right). We note that ternary complexes formed by IVT SAP-1b, a splice variant lacking the carboxy-terminal MAPK consensus sites (Dalton and Treisman 1992), did not comigrate with any of the mouse complexes and were unaffected by ERK-2 treatment (data not shown).

\section{Modification of TCF/Elk-1, but not of TCF/SAP-1, is dependent on Ras activation}

The experiments described above implied the existence of two distinct signal transduction pathways targeting TCF/Elk-1 and TCF/SAP-1, respectively, and diverging at the level of MAPK activation. To test whether these pathways differed in their requirements for intracellular signal transducers upstream of this divergence point, we assayed the dependence of TCF/Elk-1 and TCF/SAP-1 modification on Ras function, protein kinase $C$ (PKC) function, and on the function of $G_{i}$ proteins. BAC$1+\operatorname{Ras}^{\mathrm{Asn} 17}$ cells were obtained by transfection. Clones inducibly expressing the recombinant proteins were selected and tested for their ability to support the modification of TCF/Elk-1 and TCF/SAP-1 upon stimulation with CSF-1. Dexamethasone-mediated induction of the Ras $^{\text {Asn } 17}$ mutant suppressed I-1 formation, whereas I-2 was unaffected (Fig. 6). Thus, TCF/Elk-1, but not TCF/ SAP-1, modification was a Ras-dependent phenomenon.

BAC-1 cells contain three PKC isozymes, namely $\delta, \epsilon$, and $\zeta$. PKC $\delta$ is hyperphosphorylated following CSF-1 treatment, and both PKC $\delta$ and $\epsilon$ are effectively downregulated by prolonged exposure to TPA /G. Varga and M. Baccarini, unpubl.). PKC down-regulation negatively affects CSF-1 mitogenic signal transduction (Imamura et al., 1990). This treament, however, did not affect the CSF-1-induced modification of TCF/Elk-1 or TCF/SAP1 , indicating that TPA-sensitive PKCs are not involved in this process (data not shown). Likewise, inhibition of $\mathrm{G}_{\mathrm{i}}$ proteins by pertussis toxin treatment, reported previously to affect CSF-1 signal transduction (Imamura et al.
1990), did not reduce TCF/Elk-1 or TCF/SAP-1 phosphorylation (data not shown).

\section{Discussion}

Two distinct TCFs are modified upon in vivo stimulation of mouse cells

Extracts from BAC-1, B82L, and NIH-3T3 cells contain

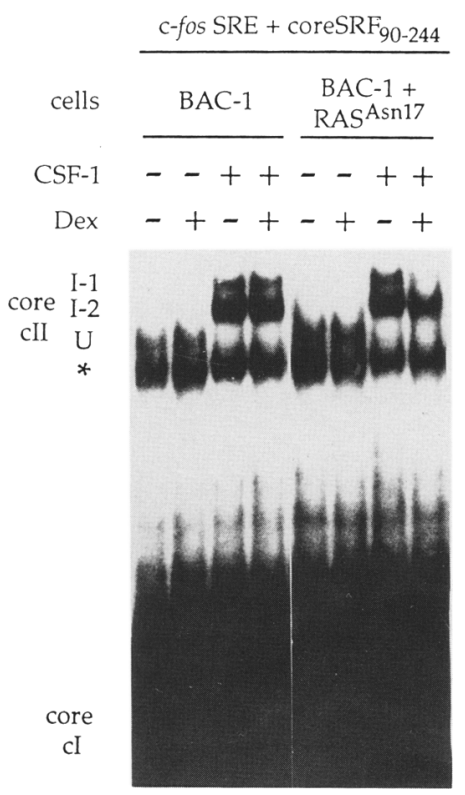

Figure 6. TCF modification in BAC-1 cells expressing inducible Ras ${ }^{\text {Asn } 17}$ constructs. Mobility-shift analysis of complexes formed by whole-cell extract from resting and CSF-1-stimulated $\mathrm{BAC}-1$ and BAC-1 + Ras ${ }^{\mathrm{Asn} 17}$ cells. Cells were either left untreated or stimulated with CSF-1 $\left(5 \mathrm{~min}\right.$ at $\left.37^{\circ} \mathrm{C}\right)$. Where indicated, dexamethasone $(0.5 \mu \mathrm{M}$ final concentration) was added to the cultures during growth factor starvation. Reactions contained ${ }^{32} \mathrm{P}$-labeled c-fos SRE and core $\mathrm{SRF}_{90-244}$. 
two distinct activities capable of forming ternary complexes on the c-fos SRE. The properties of these two TCFs are identical in four respects: (1) They both bound the E74 ETS recognition sequence directly; (2) both were unable to form ternary complexes on SRE probes carrying a mutation of the TCF contact points; $(3)$ they both formed ternary complexes with core SRF or core MCM1; and (4) they were hyperphosphorylated when the cells were stimulated in vivo. The two activities could be distinguished, on the basis of their reactivity with specific antisera, as Elk-1- and SAP-1-related TCFs. Both TCF/ Elk-1 and TCF/SAP-1 could be detected in the mouse cell lines tested, where the relative proportion of TCF/ SAP-1 was much higher than in a number of human cell lines (Fig. 2B; R. Hipskind and M. Baccarini, unpubl.).

Extracts from uninduced mouse cells contained two ternary complexes, labeled $U$ and ${ }^{*}$, and $U$ disappeared after in vivo stimulation of the cells. As judged by the effects of the Elk-1 and the SAP-1 antisera, the U complexes contain more TCF/SAP-1 than TCF/Elk-1, which seems to be present in both complexes $U$ and *. Upon stimulation, ternary complexes appeared that migrated with discrete mobilities and contained predominantly TCF/SAP-1 or TCF/Elk-1. Both complexes were induced concomitantly, but the modified TCF/SAP-1 complex persisted long after the TCF/Elk-1 complex had decayed. The antisera used to identify the components in the ternary complexes immunoprecipitated distinct phosphoproteins from BAC-1 cell lysates. Consistent with the induction-related appearance of altered ternary complexes, TCF/Elk-1 and TCF/SAP-1 are hyperphosphorylated after CSF-1 induction.

We did not observe obvious changes in the binding affinity of either TCF upon stimulation. Because the pattern of DNA contacts in ternary complexes containing either SAP-1 or Elk-1 are identical (Dalton and Treisman 19921, these data are consistent with the observation that the genomic footprint at the c-fos SRE remains unchanged throughout growth factor stimulation (Herrera et al. 1989; König 1991). Thus, it is possible that Elk-1 or SAP-1 may bind interchangeably to the SRE in cells expressing both of these TCFs.

\section{Separate signal transduction pathways are involved in TCF/Elk-1 and TCF/SAP-1 modification}

Phosphorylation of TCF/Elk-1 correlates temporally with c-fos induction in vivo (Zinck et al. 1993), and MAPK has been shown to phosphorylate both TCF and human Elk-1 in vitro (Fig. 5; Gille et al. 1992; Janknecht et al. 1993; Marais et al. 1993). Furthermore, mutation of the conserved MAPK-phosphorylation sites in the carboxyl terminus of Elk-1-GAL4 fusion proteins reduces their in vivo trans-activating ability (Janknecht et al. 1993; Marais et al. 1993). These data corroborate those showing that TCF helps mediating c-fos activation in vivo (Shaw et al. 1989; Graham and Gilman 1991) and define Elk-1 as a growth factor-regulated transcription factor (Janknecht et al. 1993; Marais et al. 1993). In CSF1 -stimulated BAC- 1 cells, the activation and repression kinetics of ERK-1/ERK-2 and the transient phosphorylation of TCF/Elk-1 could be tightly correlated. Furthermore, growth factor-independent, v-raf-expressing BAC-1 cells showed suppression of MAPK activation and TCF/ Elk-1 modification, seemingly as a function of the amount of viral protein expressed (Büscher et al. 1993). In contrast, modified TCF/SAP-1 persisted long after MAPK and TCF/Elk-1 had returned to their basal state after CSF-1 stimulation of BAC-I cells and could still be detected in v-raf-expressing cells upon growth factor stimulation.

Likewise, in fibroblasts expressing hEGFR or mutants thereof, only hEGFR forms capable of activating MAPK led to TCF/Elk-1 modification. In contrast, TCF/SAP-1 was modified upon EGF stimulation irrespective of MAPK and RAF-1 activation. Essentially similar results were observed in NIH-3T3 cells, in which ERK-1 and ERK-2 are weakly active $7.5 \mathrm{~min}$ after serum induction (Fig. 4A). Accordingly, modification of TCF/SAP-1, but not of TCF/Elk-1, was detected in extracts prepared from induced NIH-3T3 cells. Nevertheless SRE-driven IE genes are serum-inducible in NIH-3T3 cells, indicating that transcription of these genes may be stimulated via a MAPK-independent signaling pathway targeting a distinct ternary complex. Alternatively, TCF may not be essential for IE gene expression in fibroblasts, as suggested by the observation that c-fos promoters carrying mutations in the TCF recognition site retain nearly full serum inducibility in these cells /Graham and Gilman 1991; König 1991).

Our results, while supporting the view that Elk-1 phosphorylation is mediated by MAPK in vivo, imply the existence of a distinct TCF/SAP-1 kinase. This was surprising, given the homology between human Elk-1 and human SAP-1. All of the MAPK phosphorylation sites required for transcriptional activation by the Elk-1 carboxy-terminal region are conserved in the C-box of SAP-1a (Dalton and Treisman 1992; Treisman 1994). SAP-1a was phosphorylated by activated MAPK in vitro; nevertheless, the mobility of SAP-1a ternary complexes was barely modified. Together with the results obtained in vivo, these data indicate that MAPK activation is neither necessary nor sufficient for TCF/SAP-1 modification.

In an effort to elucidate the pathway leading to TCF/ SAP-1 activation, we blocked the activation of different molecules involved in CSF-1 signal transduction. Both TCF/SAP-1 and TCF/Elk-1 were resistant to TPA-mediated PKC down-regulation and to inhibition of $G_{i}$ proteins by pertussis toxin treatment. Interestingly, however, TCF/SAP-1, but not TCF/Elk-1, was resistant to Ras inactivation by the expression of the dominant-negative $\operatorname{Ras}^{\text {Asn } 17}$ mutant. Thus, the pathways leading to TCF/SAP-1 and /Elk-1 activation already diverge at the level of Ras activation.

Implications for signal transduction and for the induction of SRE-driven IE genes

The strong correlation among Ras activity, ERK-1/ 
ERK-2 activity, TCF/Elk-1 phosphorylation, and IE gene transcription (Zinck et al. 1993; R. Hipskind, M. Baccarini, and A. Nordheim, in prep.) indicates that the Ras $\rightarrow$ MAPK $\rightarrow$ TCF/Elk-1 signaling cascade is one of the primary ways by which the CSF-1 signal reaches the nucleus.

RAF-1 has been implicated as an intermediate in this pathway (Dent et al. 1992; Howe et al. 1992; Kyriakis et al. 1992; Lange-Carter et al. 1993; Moodie et al. 1993; van Aelst et al. 1993). However, the pathways leading to ERK-1/ERK-2 activation in BAC-1 cells are down-regulated by v-raf expression, seemingly because of the v-rafdependent, constitutive expression of a phosphatase implicated in MAPK regulation (S. Krautwald, D. Büscher, and M. Baccarini, in prep.; Alessi et al. 1993). The existence of this negative feedback loop underscores the complexity of intracellular signaling pathways.

The MAPK regulatory network involves at least two distinct, possibly independently regulated kinases, MEK kinase and RAF-1, both capable of phosphorylating MEK-1 in vitro (Lange-Carter et al. 1993 and references therein). In addition, Ras-independent pathways can participate in MAPK activation in vivo (de Vries-Smits et al. 1992). Thus, the activation of MAPK and thereby TCF/ Elk-1 phosphorylation represents a point of convergence for multiple signals activating IE gene expression.

Our data show for the first time that a ternary complex formed by a TCF immunologically related to SAP-1 is modified upon factor stimulation in vivo. Notably, the enzyme phosphorylating TCF/SAP-1 is distinct from MAPK and independent of Ras activity. Furthermore, the persistence of the modified TCF/SAP-1 complexes long after the decay of the modified TCF/Elk-1 complexes also implies that TCF/SAP-1 is not a substrate for the phosphatase activity likely to be responsible for down-regulation of TCF/Elk-1 (Fig. 1B, also see Zinck et al. 1993). The signaling molecules targeting TCF/SAP-1 after in vivo stimulation of mouse cells are therefore distinct from those acting on TCF/Elk-1.

TCF/SAP-1 represents the second example of a transcription factor phosphorylated by Ras-independent mechanisms upon growth factor stimulation. The nuclear factor p91, originally described as an interferoninduced DNA-binding activity, is phosphorylated on tyrosine in a Ras-independent manner following stimulation with EGF, platelet-derived growth factor (PDGF), and CSF-1 (Silvennoinen et al. 1993). However, the pathways leading to TCF/SAP-1 and p91 modification are very likely different. A truncated EGFR lacking the five autophosphorylation sites fails to activate $\mathrm{p} 91$ (Silvennoinen et al. 1993) but is still fully capable of supporting TCF/SAP-1 modification (Fig. 4B). Interestingly, p91 also binds to a regulatory element in the c-fos promoter, the SIE (sis-inducible element).

We do not know at present what role, if any, TCF/ SAP-1 plays in IE gene induction. This factor is the major activity in serum-induced NIH-3T3 cells, in M721-B82L cells, and in CSF-1-stimulated BAC-1 + RAS ${ }^{\mathrm{Asn} 17}$ and Vrb- 6 cells. IE genes are activated under these conditions, albeit to different degrees (Honegger et al. 1987;
Büscher et al. 1993|. Therefore, one attractive possibility is that TCF/Elk-1 functions as signal acceptor of Ras/ MAPK-dependent pathways, whereas TCF/SAP-1 and p91 operate in Ras-independent cascades to mediate the induction of different sets of IE genes. Additionally, TCF/SAP-1 may functionally substitute for TCF/Elk-1 in situations where the signal transduction pathways leading to the activation of the latter factor are not operating.

\section{Materials and methods}

\section{Cell culture}

BAC-1.2F5 cells (Morgan et al. 1987) and derived clones were cultured in Dulbecco's modified Eagle medium (DMEM) supplemented with $15 \%$ fetal calf serum (FCS) and 0.63 nM purified mouse recombinant CSF-1 (Krautwald and Baccarini 1993) or $15 \%$ L-cell conditioned medium (Stanley 1985) as a source of murine CSF-1. BAC-1 + RAS ${ }^{\text {Asn17 }}$ cells were generated by electroporating BAC-1.2F5 cells with the plasmid pMMTVrasH (Asn-17) (Cai et al. 1990), kindly provided by Dr. G. Cooper. Several clones were obtained and tested for inducible construct expression by Western blot analysis and immunohistochemistry. Clones showing the strongest inducible expression were selected and used in this study. HeLa, NIH-3T3 cells, and permanent clonal B82L transfectants expressing the various EGFR constructs (Chen et al. 1989) were cultured in DMEM supplemented with $10 \%$ FCS.

\section{Growth factor stimulation}

Confluent cultures of BAC-1.2F5, Vrb-B, or Vrb- 6 cells $110^{7}$ cells/100-mm tissue culture dish) were cultured in medium without CSF-1 for $18 \mathrm{hr}$ to up-regulate receptors prior to stimulation with recombinant CSF-1 $6.3 \mathrm{~nm}$ mouse recombinant CSF-1) for different periods of time. In selected experiments, down-modulation of PKC was performed by treating the cultures with $5 \times 10^{-6} \mathrm{M}$ phorbol 12 -myristate 13 -acetate (Sigma) in dimethylsulfoxide (14 $\mathrm{mm}$ final concentration) or with dimethylsulfoxide alone for $24 \mathrm{hr}$. Pertussis toxin-sensitive G-proteins were inhibited by treating the cells with pertussis toxin (Sigma, $100 \mathrm{ng} / \mathrm{ml}$ final concentration/ for $4 \mathrm{hr}$ before stimulation with CSF-1. BAC-1 + RAS ${ }^{\text {Asn17 }}$ cells were starved in DMEM/15\% FCS supplemented with dexamethasone $(0.5 \mu \mathrm{M}$; Sigma $)$ to induce the expression of the Ras construct. NIH-3T3 cells were starved in $0.05 \%$ FCS for $18 \mathrm{hr}$ prior to stimulation with $10 \%$ FCS. B82L transfectants were starved in $0.05 \%$ FCS, $1 \mu \mathrm{M}$ methotrexate, for $18 \mathrm{hr}$ prior to stimulation with $100 \mathrm{~nm}$ EGF. HeLa cells were fully serum-deprived for 15-18 hr before serum induction. Incubations were terminated by aspirating the medium and washing five times with ice-cold PBS. Cells were lysed in solubilization buffer $(10 \mathrm{~mm}$ Tris- $\mathrm{Cl}, 50 \mathrm{~mm} \mathrm{NaCl}, 1 \%$ Triton $\mathrm{X}-100,30 \mathrm{mM}$ sodium pyrophosphate, $50 \mathrm{mM} \mathrm{NaF}, 100 \mu \mathrm{M}$ $\mathrm{Na}_{3} \mathrm{VO}_{4}, 2 \mu \mathrm{M} \mathrm{ZnCl}, 1 \mathrm{mM}$ PMSF). Insoluble material was removed by centrifugation $\left(15,000 \mathrm{rpm}\right.$ for $30 \mathrm{~min}$ at $\left.4^{\circ} \mathrm{C}\right)$.

\section{Western blotting}

Cell lysates $(20 \mu \mathrm{g} /$ lane) were separated by $7.5 \%$ SDS-PAGE prior to electrophoretic transfer onto Hybond $C$ super (Amersham Buchler GmbH and Co. KG, Braunschweig, Germany). The blots were blocked with $5 \%$ nonfat dry milk (Bio-Rad) and incubated with a rabbit polyclonal antiserum raised to the peptide ITVEEALAHPYLEQYYDPTFDEPV, based on the ERK-1 se- 
quence (Adams and Parker 1991) to detect MAPKs. The blots were subsequently incubated for $1 \mathrm{hr}$ at room temperature with donkey-anti-rabbit horseradish peroxidase-conjugated antibodies prior to exposure to the ECL substrate. All Western blotting reagents were from Amersham.

\section{In-gel kinase assay}

Samples containing $7.5 \mu \mathrm{g}$ (BAC-1, Vrb.B, and Vrb-6 cells) or 15 $\mu \mathrm{g}$ of protein were made to $62.5 \mathrm{~mm}$ Tris- $\mathrm{HCl}(\mathrm{pH} 6.8), 2.3 \%$ SDS, $5 \mathrm{~mm}$ EDTA, $10 \%$ glycerol, and $100 \mathrm{~mm}$ DTT and heated at $85^{\circ} \mathrm{C}$ for $5 \mathrm{~min}$ before SDS-PAGE. The separating gels were polymerized with $0.2 \mathrm{mg} / \mathrm{ml}$ of myelin basic protein (Sigma) and after electrophoresis denatured in $6 \mathrm{~m}$ guanidine- $\mathrm{HCl}$, renatured, and assayed for kinase activity as described in Chao et al. (1992).

\section{Mobility-shift assays}

Reactions (7.5 $\mu$ l) contained the following components: $2.5 \mu \mathrm{g}$ of poly[d(I-C)], $250 \mathrm{ng}$ of salmon sperm DNA, 5\% glycerol, 66 $\mathrm{mm} \mathrm{NaCl}, 10 \mathrm{~mm}$ Tris- $\mathrm{HCl}(\mathrm{pH} 7.5), 1 \mathrm{~mm}$ EDTA, $0.35 \%$ Triton $\mathrm{X}-100,0.05 \%$ low-fat milk, $15 \mathrm{~mm}$ DTT, 10,000-15,000 cpm of ${ }^{32} \mathrm{P}$-labeled probe $(0.2 \mathrm{ng} / 4 \mathrm{fmole})$, and $5-10 \mu \mathrm{g}$ of protein. The high concentration of phosphatase inhibitors in the whole-cell extracts ensured inhibition during the binding reaction. After $30 \mathrm{~min}$ at room temperature, the entire reaction was loaded on a $4 \%$ polyacrylamide $(29: 1$ acrylamide/bis) gel containing $0.5 \times$ TBE and run at $1 \mathrm{~mA} / \mathrm{cm}$ for 3-4 hr. Gels were dried and the complexes visualized by autoradiography with intensifying screens. Competitions were performed with wild-type (core sequence CCGGAAG) or mutant (core sequence CCCCAAG) E74 double-stranded oligonucleotides as described (Janknecht and Nordheim 1992; Zinck et al. 1993). core $\mathrm{SRF}_{90-244}$ was produced in HeLa cells using a recombinant vaccinia virus (Hipskind et al. 1991; R. Hipskind, J. Schmitt, H. Stunnenberg, and A. Nordheim, in prep.), core MCM1 was produced by coupled transcription/translation as described (Mueller and Nordheim 1991), and recombinant human Elk-1 was generated by overexpression in HeLa cells (Janknecht and Nordheim 1992). The Elk-1 and SAP-1 antisera were added to the reactions before addition of the extracts. The specificity of the Elk-1 antiserum has been documented elsewhere (Hipskind et al. 1991). The SAP-1 antiserum, graciously provided by Dr. R. Treisman, was raised against a glutathione $S$-transferase (GST) fusion protein including the entire sequence of clone 18 described by Dalton and Treisman (1992). It does not cross-react with Elk-1 or SAP-2 in immunoprecipitation experiments (A. Rogers, S. Dalton, and R. Treisman, unpubl.). All probes were prepared from fragments subcloned in front of a G-free cassette plasmid (Hipskind and Nordheim 1991). After EcoRI and NarI digestion, the ends were labeled by a Klenow fill-in reaction containing $\left[\alpha{ }^{32} \mathrm{P}\right] \mathrm{dATP}$ and cold dCTP, dGTP, and TTP. The fragments were isolated from polyacrylamide gels by electroelution. The same amount of extract protein was used in each reaction within experiments to allow direct comparison between lanes.

\section{Phosphatase treatment}

For BAP treatment extracts were dialyzed against $10 \mathrm{~mm}$ Tris$\mathrm{HCl}(\mathrm{pH} 8.0), 50 \mathrm{~mm} \mathrm{NaCl}, 5 \mathrm{~mm} \mathrm{MgCl}$, and $20 \mu \mathrm{g} / \mathrm{ml}$ of aprotinin. Dialyzed extracts were incubated at $30^{\circ} \mathrm{C}$ for $45 \mathrm{~min}$ in this buffer either without or with 130 nanounits of BAP (Sigma). For PP- $1 \alpha$ and PP-2A the extracts were dialyzed against $20 \mathrm{~mm}$ Tris- $\mathrm{HCl}$ (pH 7.4), $50 \mathrm{~mm} \mathrm{NaCl}, 0.1 \mathrm{~mm}$ EGTA, $0.5 \mathrm{~mm}$ DTE, and $0.5 \mathrm{~mm}$ benzamidine. Reactions were incubated as described in Zinck et al. (1993) with 0.6 milliunits of the respective phosphatase, both of which were kindly provided by Dr. G. Mieskes. Addition of $15 \mathrm{~mm} \mathrm{NaF}, 30 \mathrm{~mm} \beta$-glycerophosphate, $15 \mathrm{~mm}$-nitrophenol phosphate, $100 \mu \mathrm{M} \mathrm{Na} \mathrm{VO}_{4}$, and 1 $\mu \mathrm{M}$ okadaic acid inhibited the phosphatases and controlled for nonspecific loss of TCF activity. After incubation at $30^{\circ} \mathrm{C}$ for 30 min, reactions were stopped by adding the inhibitor mixture listed above, and an aliquot was added to a normal mobilityshift reaction. The reactions in lanes marked with the minus (Fig. lB) were assembled with the dialyzed extract without incubation at $30^{\circ} \mathrm{C}$. The same phosphatase inhibitor mixture described above was used in the control reactions.

\section{In vitro kinase reactions}

Human Elk-1 and SAP-la cRNAs were synthesized from linearized vectors by use of the appropriate RNA polymerases. The SAP-1 cDNA subclones (Dalton and Treisman 1992) were generously provided by Dr. R. Treisman. After the quality of the cRNA was confirmed, proteins were synthesized in vitro with nuclease-treated rabbit reticulocyte lysates as described (Hipskind et al. 1991). Proteins were either labeled with $\left[{ }^{35} \mathrm{~S}\right] \mathrm{methio-}$ nine (for the in vitro kinase assays) or synthesized cold with unlabeled amino acid mixes to avoid the presence of ${ }^{35} \mathrm{~S}$ clouds in the gels for the mobility-shift analysis. SDS-PAGE showed similar amounts of Elk-1 and SAP-la per microliter of translation mix. For the mobility-shift analysis, $1 \mu l$ of a 10 -fold dilution of each protein was mixed with $1 \times$ mobility-shift buffer plus $20 \mathrm{~mm}$ Tris- $\mathrm{HCl}$ (pH 7.3), $10 \mathrm{mM} \mathrm{MgCl}_{2}$, protease and phosphatase inhibitors, activated ERK-2 (where indicated; $6.25 \mathrm{ng}$ / reaction; sp. act.: 4 mmoles of phosphate transferred to $\mathrm{MBP} /$ min per mg-activated ERK-2|, and $1 \mathrm{mM}$ cold ATP in a 7.5- $\mu \mathrm{l}$ reaction. After incubation at $30^{\circ} \mathrm{C}$ for $60 \mathrm{~min}, 2 \mu \mathrm{l}$ of this mixture was used in a mobility-shift reaction, and the rest was analyzed by SDS-PAGE. Mobility-shift reactions were also assembled with unincubated in vitro-translated proteins and uninduced and induced BAC-1 and HeLa whole-cell extracts. For the in vitro kinase assays, equivalent amounts of ${ }^{35} \mathrm{~S}$-labeled proteins were incubated in the presence or absence of activated ERK-2 as described above, except that $300 \mathrm{nM}\left[\mathrm{y}^{32} \mathrm{P}\right] \mathrm{ATP}$ (Amersham; sp. act. $3000 \mathrm{Ci} / \mathrm{mmole}$ ) was used instead of $1 \mathrm{~mm}$ cold ATP. After incubation at $30^{\circ} \mathrm{C}$ for $60 \mathrm{~min}$, the reactions were diluted with $300 \mu \mathrm{l}$ of solubilization buffer and incubated with a 1:40 dilution of either an ETS-domain-specific anti-Elk-1 serum (Zinck et al. 1993) or an anti-SAP-1 (A. Rogers, S. Dalton, and R. Treisman, unpubl.) serum for $3 \mathrm{hr}$ at $4^{\circ} \mathrm{C}$. Immunocomplexes were collected by reaction $\left(45 \mathrm{~min}\right.$ at $\left.4^{\circ} \mathrm{C}\right)$ with protein A-Sepharose beads. The beads were washed four times in icecold lysis buffer and eluted by boiling in Laemmli sample buffer. The eluates were separated on $10 \%$ SDS-PAGE, and the gels were subjected to autoradiography at $4^{\circ} \mathrm{C}$ by use of Kodak XAR 5 films.

Bacterial ERK-2 was activated in vitro by incubation with activated MEK-1 (purified from insect cells coinfected with baculovirus recombinant viruses encoding Ras, Src, and MEK-1; sp. act.: $0.2 \mu$ mole of phosphate transferred to catalytically inactive ERK- $2 /$ min per mg of MEK- 1 , purified, and stored in $50 \%$ glycerol at a concentration of $12.5 \mathrm{ng} / \mathrm{ml}$. The activity of this preparation of activated ERK-2 is greater than or equal to the activity of ERK-2 conventionally purified from stimulated eukaryotic cells. Activated ERK-2 was kindly provided by Dr. P. Dent.

\section{RNA isolation and analysis}

Aliquots of whole-cell extracts were mixed with an equal volume of $0.2 \mathrm{M}$ Tris- $\mathrm{HCl}(\mathrm{pH} 7.5), 0.44 \mathrm{M} \mathrm{NaCl}, 2 \%$ SDS, and 25 
$\mathrm{mM}$ EDTA. Proteinase $\mathrm{K}$ was added to $0.2 \mathrm{mg} / \mathrm{ml}$, and the mix ture was incubated at $37^{\circ} \mathrm{C}$ for $30-60 \mathrm{~min}$ (Greenberg 1989). After organic extraction the RNA was collected by ethanol precipitation. Total RNA (10 $\mu$ g per lane) was loaded on formaldehyde-agarose gels, while $2.5 \mu \mathrm{g}$ RNA/slot was blotted onto positively charged nylon membranes in cold $10 \mathrm{mM} \mathrm{NaOH}, 1 \mathrm{~mm}$ EDTA. These filters were then processed as for the Northern transfers, which have been described previously along with the hybridization protocol (Zinck et al. 1993). After hybridization the filters were stripped for $30 \mathrm{~min}$ at room temperature in three changes of $30 \mathrm{~mm} \mathrm{NaOH}, 1 \%$ SDS, washed in $25 \mathrm{~mm} \mathrm{NaPO}_{4} / \mathrm{pH}$ 6.8 ), followed by $0.2 \times$ SSC, $1 \%$ SDS, and then reprobed. The riboprobes corresponded to the first exon of the human c-fos gene, the entire rat GAPDH cDNA, and a BglII fragment from the mouse EGR-1 cDNA. RNA was quantitated by scanning $\mathrm{X}$-ray films and normalized to the GAPDH signal.

\section{Acknowledgments}

The skillful technical assistance of Karin Ruthenberg and Christa Kurth is gratefully acknowledged. We also thank Dr. Geoffrey Cooper (Dana Farber Institute for Cancer Research, Harvard Medical School, Boston) for the gift of the pMMTVrasH and pMMTVrasH(Asn-17) plasmids, Dr. P. Dent (Department of Internal Medicine and Pharmacology, University of Virginia Health Science Center, Charlottesville) for providing activated ERK-2, Dr. G.N. Gill (Department of Medicine, University of California, San Diego, La Jolla) for the B82L cells expressing the EGFR constructs, Dr. G. Mieskes (University of Göttingen) for purified PP-1 $\alpha$ and PP-2A, Dr. P. Parker (ICRF, London) for the gift of MAPK antiserum, Dr. R. Zinck and Dr. R. Janknecht (Institute for Molecular Biology, Hannover Medical School) for providing anti-Elk sera and rhElk-1 protein, respectively. We are especially indebted to Dr. R. Treisman (ICRF, London) for providing the SAP-1 antiserum and the SAP-1 cDNA subclones. The manuscript was improved by the critical comments of Drs. T. Decker, R. Janknecht, L.-G. Larsson, M. Cahill, W. Ernst, M. Henriksson, D. Evans and G. Bilbe. This work was supported by grant 10211 of the Dr. Mildred-Scheel-Stiftung, Bonn, Germany (to M.B.), by DFG grant 120/7-1 (to A.N.), and by the Fonds der Chemischen Industrie (to A.N.).

The publication costs of this article were defrayed in part by payment of page charges. This article must therefore be hereby marked "advertisement" in accordance with 18 USC section 1734 solely to indicate this fact.

\section{References}

Adams, P.D. and P.J. Parker. 1991. TPA-induced activation of MAP kinase. FEBS Lett. 290: 77-82.

Alessi, D.R., C. Smythe, and S.M. Keyse. 1993. The human CL100 gene encodes a Tyr/Thr-protein phosphatase which potently and specifically inactivates MAP kinase and suppresses its activation by oncogenic ras in Xenopus oocyte extracts. Oncogene 8: 2015-2020.

Baccarini, M. and E.R. Stanley. 1990. Colony stimulating factor1. In Growth factors, differentiation factors, and cytokines (ed. A. Habenicht), pp. 188-200. Springer Verlag, Berlin, Germany.

Baccarini, M., D.M. Sabatini, H. App, U.R. Rapp, and E.R. Stanley. 1990. Colony-stimulating factor-1 (CSF-1) stimulates the temperature-dependent phosphorylation and activation of the RAF-1 protooncogene product. EMBO I. 9: 3649-3657.

Baccarini, M., G.N. Gill, and E.R. Stanley. 1991. Epidermal growth factor stimulates phosphorylation of RAF-1 indepen- dently of receptor autophosphorylation and internalization. J. Biol. Chem. 266: 10941-10945.

Bortner, D.M., M. Ulivi, M.F. Roussel, and M.C. Ostrowski. 1991. The carboxy-terminal catalytic domain of GTPase-activating protein inhibits nuclear signal transduction and morphological transformation by the CSF-1 receptor. Genes \& Dev. 5: 1777-1785.

Büscher, D., P. Dello Sbarba, R.A. Hipskind, U.R. Rapp, E.R. Stanley, and M. Baccarini. 1993. v-raf confers CSF-1 independent growth to a macrophage cell line and leads to immediate early gene expression without MAP-kinase activation. Oncogene 8: 3323-3332.

Cai, H., J. Szebereny, and G.M. Cooper. 1990. Effect of a dominant inhibitory $\mathrm{Ha}$-ras mutation on mitogenic signal transduction in NIH 3T3 cells. Mol. Cell. Biol. 10: 5314-5323.

Campos-González, R. and J.R. Glenney, Jr. 1992. Tyrosine phosphorylation of mitogen-activated protein kinase in cells with tyrosine kinase-negative epidermal growth factor receptors. J. Biol. Chem. 267: 14535-14538.

Chao, T.-S.O., K.L. Byron, K.-M. Lee, M. Villereal, and M.R. Rosner. 1992. Activation of MAP kinases by calcium-dependent and calcium-independent pathways. J. Biol. Chem. 267: 19876-19883.

Chen, W.S., C.S. Lazar, K.A. Lund, J.B. Welsh, C.-P. Chang, G.M. Walton, C.J. Der, H.S. Wiley, G.N. Gill, and M.G. Rosenfeld. 1989. Functional independence of the epidermal growth factor receptor from a domain required for ligandinduced internalization and calcium regulation. Cell 59: 3343.

Dalton, S. and R. Treisman. 1992. Characterization of SAP-1, a protein recruited by serum response factor to the c-fos serum response element. Cell 68: 597-612.

de Vries-Smits, A.M.M., B.M.T. Burgering, S.J. Leevers, C.J. Marshall, and J.L. Bos. 1992. Involvement of $\mathrm{p} 21^{\text {ras }}$ in activation of extracellular signal-regulated kinase 2. Nature 357: 602-604.

Dent, P., W. Haser, T.A. Haystead, L.A. Vincent, T.M. Roberts, and T.W. Sturgill. 1992. Activation of mitogen-activated protein kinase by v-raf in NIH 3T3 cells and in vitro. Science 257: 1404-1407.

Gallego, C., S.K. Gupta, L.E. Heasley, N.-X. Qian, and G.L. Johnson. 1992. Mitogen-activated protein kinase activation resulting from selective oncogene expression in NIH 3T3 and Rat la cells. Proc. Natl. Acad. Sci. 89: 7355-7359.

Gille, H.G., A.D. Sharrocks, and P.E. Shaw. 1992. Phosphorylation of transcription factor p62 $2^{\mathrm{TCF}}$ by MAP kinase stimulates ternary complex formation at c-fos promoter. Nature 358: 414-417.

Graham, R. and M. Gilman. 1991. Distinct protein targets for signals acting at the c-fos serum response element. Science 251: $189-192$.

Greenberg, M. 1989. Identification of newly transcribed RNA. In Current protocols in molecular biology (ed. F.M. Ausubel, R. Brent, R.E. Kingston, D.D. Moore, J.G. Seidman, J.A. Smith, and K. Struhl), vol. I, pp. 4.10.1-4.10.9. John Wiley and Sons, New York.

Gupta, S.K., C. Gallego, G.L. Johnson, and L.E. Heasley. 1992. MAP-kinase is constitutively activated in gip2 and src transformed Rat la fibroblasts. J. Biol. Chem. 267: 7987-7990.

Herrera, R.E., P.E. Shaw, and A. Nordheim. 1989. Occupation of the $\mathrm{c}$-fos serum response element in vivo by a multi-protein complex is unaltered by growth factor induction. Nature 340: $68-70$.

Hill, C.S., R. Marais, S. John, J. Wynne, S. Dalton, and R. Treisman. 1993. Functional analysis of a growth factor-responsive transcription factor complex. Cell 73: 395-406. 
Hipskind, R.A. and A. Nordheim. 1991. In vitro transcriptional analysis of the human c-fos proto-oncogene. J. Biol. Chem. 266: 19572-19582.

Hipskind, R.A., V.N. Rao, C.G.F. Mueller, E.S.P. Reddy, and A. Nordheim. 1991. Ets-related protein Elk-1 is homologous to the c-fos regulatory factor p62 ${ }^{\mathrm{TCF}}$. Nature 354: 531-534.

Hipskind, R.A., M. Baccarini, and A. Nordheim. 1994. Transient activation of RAF-1, MEK and ERK2 coincides kinetically with TCF phosphorylation and IEG promoter activity in vivo. Mol. Cell. Biol. 14: (in press).

Honegger, A.M., D. Szapary, A. Schmidt, R. Lyall, E. Van Obberghen, T.J. Dull, A. Ullrich, and J. Schlessinger. 1987. A mutant epidermal growth factor receptor with defective protein tyrosine kinase is unable to stimulate proto-oncogene expression and DNA synthesis. Mol. Cell. Biol. 7: 45684571.

Howe, L.R., S.J. Leevers, N. Gómez, S. Nakielny, P. Cohen, and C. Marshall. 1992. Activation of the MAP kinase pathway by the protein kinase raf. Cell 71: 335-342.

Imamura, K., A. Dianoux, T. Nakamura, and D. Kufe. 1990. Colony-stimulating factor-1 activates protein kinase $\mathrm{C}$ in human monocytes. EMBO J. 9:2423-2429.

Janknecht, R. and A. Nordheim. 1992. Elk-1 protein domains required for direct and SRF-assisted DNA-binding. Nucleic Acids Res. 20: 3317-3324.

Janknecht, R., W.H. Ernst, V. Pingoud, and A. Nordheim. 1993. Activation of ternary complex factor Elk-1 by MAP kinases. EMBO I. 12: 5097-5104.

König, H. 1991. Cell-type specific multiprotein complex formation over the $\mathrm{c}$-fos serum response element in vivo: Ternary complex formation is not required for the induction of $\mathrm{c}$-fos. Nucleic Acids Res. 19: 3607-3611.

Krautwald, S. and M. Baccarini. 1993. Bacterially expressed CSF-1 possesses agonistic activity in its monomeric form. Biochem. Biophys. Res. Commun. 192: 720-727.

Kyriakis, J.M., H. App, X.-F. Zhang, P. Banerjee, D.L. Brautigan, U.R. Rapp, and J. Avruch. 1992. Raf-1 activates MAP kinasekinase. Nature 340: 417-421.

Lange-Carter, C.A., C.M. Pleiman, A.M. Gardner, K.J. Blumer, and G.L. Johnson. 1993. A divergence in the MAP kinase regulatory network defined by MEK kinase and Raf. Science 260: 315-319.

Marais, R., J. Wynne, and R. Treisman. 1993. The SRF accessory protein Elk-1 contains a growth factor-regulated transcriptional activation domain. Cell 73: 381-393.

Moodie, S.A., B.M. Willumsen, M.J. Weber, and A. Wolfman. 1993. Complexes of Ras-GTP with Raf-1 and mitogen-activated protein kinase kinase. Science 260: 1658-1661.

Morgan, C., J.W. Pollard, and E.R. Stanley. 1987. Isolation and characterization of a cloned growth factor dependent macrophage cell line, BAC-1.2F5. J. Cell. Physiol. 130: 420-427.

Mueller, C.G.F. and A. Nordheim. 1991. A protein domain conserved between yeast MCM1 and human SRF directs ternary complex formation. EMBO I. 10: 4219-4229.

Norman, C., M. Runswick, R. Pollock, and R. Treisman. 1988. Isolation and properties of cDNA clones encoding SRF, a transcription factor that binds to the c-fos serum response element. Cell 55: 989-1003.

Rao, V.N. and E.S.P. Reddy. 1992. A divergent ets-related protein, elk-1, recognizes similar c-ets-1 proto-oncogene target sequences and acts as a transcriptional activator. Oncogene 7: 65-70.

Rao, V.N., K. Huebner, M. Isobe, A. Ar-Rushdie, C.M. Croce, and E.S.P. Reddy. 1989. elk, tissue-specific ets-related genes on chromosomes $\mathrm{X}$ and 14 near translocation breakpoints. Science 244: 66-70.
Rapp, U.R. 1991. Role of Raf-1 serine/threonine protein kinase in growth factor signal transduction. Oncogene 6: 495-500.

Samuels, M.L., M.J. Weber, J.M. Bishop, and M. McMahon. 1993. Conditional transformation of cells and rapid activation of the mitogen-activated protein kinase cascade by an estradiol-dependent human Raf-1 protein kinase. Mol. Cell. Biol. 13: 6241-6252.

Schröter, H., C.G.F. Mueller, K. Meese, and A. Nordheim. 1990. Synergism in ternary complex formation between the dimeric glycoprotein $\mathrm{p} 67^{S R F}$, polypeptide $\mathrm{p} 62^{T C F}$ and the c-fos serum response element. EMBO I. 9: 1123-1130.

Selva, E., D.L. Raden, and R.J. Davis. 1993. Mitogen-activated protein kinase stimulation by a tyrosine kinase-negative epidermal growth factor receptor. I. Biol. Chem. 268: 22502254.

Shaw, P.E. 1992. Ternary complex formation over the c-fos serum response element: $\mathrm{p} 62^{\mathrm{TCF}}$ exhibits dual component specificity with contacts to DNA and an extended structure in the DNA-binding domain of p67 ${ }^{\mathrm{SRF}}$. EMBO I. 11: 30113019.

Shaw, P.E., H. Schröter, and A. Nordheim. 1989. The ability of a ternary complex to form over the serum response element correlates with serum inducibility of the human c-fos promoter. Cell 56: 563-572.

Sherr, C.J., C.W. Rettenmier, R. Sacca, M.F. Roussel, A.T. Look, and E.R. Stanley. 1985. The c-fms protoocogene product is related to the receptor for the mononuclear phagocyte growth factor, CSF-1. Cell 41: 665-676.

Silvennoinen, O., C. Schindler, J. Schlessinger, and D. Levy. 1993. Ras-independent growth factor signaling by transcription factor tyrosine phosphorylation. Science 261: 17361739.

Smith, M.R., S.J. De Gudicibus, and D.W. Stacey. 1986. Requirement for c-ras proteins during viral oncogene transformation. Nature 320: 540-543.

Stanley, E.R. 1985. The macrophage colony-stimulating factor, CSF-1. Methods Enzymol. 116: 565-587.

Thomas, S.M., M. DeMarco, G. D'Arcangelo, S. Halegoua, and J.S. Brugge. 1992. Ras is essential for nerve growth factorand phorbol ester-induced tyrosine phosphorylation of MAP kinases. Cell 68: 1031-1040.

Treisman, R. 1986. Identification of a protein-binding site that mediates the transcriptional response of the c-fos gene to serum factors. Cell 46: $567-574$

- 1994 . Ternary complex factors: Growth factor regulated transcriptional activators. Curr. Opin. Genet. Dev. 4: 96101

Troppmair, J., J.T. Bruder, H. App, H. Cai, L. Liptak, J. Szeberény, G.M. Cooper, and U.R. Rapp. 1992. Ras controls coupling of growth factor receptors and protein kinase $\mathrm{C}$ in the membrane to Raf-1 and B-Raf protein serine kinases in the cytosol. Oncogene 7: 1867-1873.

van Aelst, L., M. Barr, S. Marcus, A. Polverino, and M. Wigler. 1993. Complex formation between Ras and Raf and other protein kinases. Proc. Nat1. Acad. Sci. 90: 6213-6217.

Vojtek, A.B., S.M. Hollenberg, and J.A. Cooper. 1993. Mammalian Ras interacts directly with the serine/threonine kinase Raf. Cell 74: 205-214.

Warne, P.H., P.R. Viciana, and J. Downward. 1993. Direct interaction of Ras and the amino-terminal region of Raf- 1 in vitro. Nature 364: 352-365.

Wood, K.W., C. Sarnecki, T.M. Roberts, and J. Blenis. 1992. ras mediates nerve growth factor receptor modulation of three signal-transducing protein kinases: MAP kinase, Raf-1, and RSK. Cell 68: 1041-1050.

Yu, C.-L., E.V. Prochownik, M.J. Imperiale, and R. Jove. 1993. 
Hipskind et al.

Attenuation of serum inducibility of immediate early genes by oncoproteins in tyrosine kinase signalling pathways. Mol. Cell. Biol. 13: 2011-2019.

Zhang, X., J. Settleman, J.M. Kyriakis, E. Takeuchi-Suzuki, S.J. Elledge, M.S. Marshall, J.T. Bruder, U.R. Rapp, and J. Avruch. 1993. Normal and oncogenic $\mathrm{p} 21^{\text {ras }}$ proteins bind to the amino-terminal regulatory domain of c-Raf-1. Nature 364: 308-313.

Zinck, R., R.A. Hipskind, V. Pingoud, and A. Nordheim. 1993. c-fos transcriptional activation and repression correlate temporally with the phosophorylation status of TCF. EMBO J. 12: $2377-2387$. 


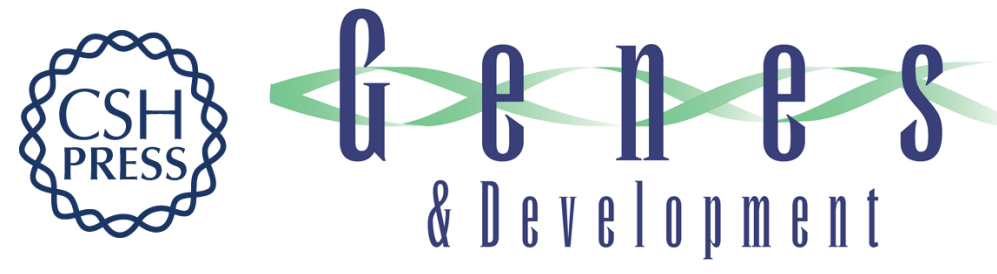

\section{Ras/MAP kinase-dependent and -independent signaling pathways target distinct ternary complex factors.}

R A Hipskind, D Büscher, A Nordheim, et al.

Genes Dev. 1994, 8:

Access the most recent version at doi:10.1101/gad.8.15.1803

References This article cites 58 articles, 19 of which can be accessed free at:

http://genesdev.cshlp.org/content/8/15/1803.full.html\#ref-list-1

License

Email Alerting

Service

Receive free email alerts when new articles cite this article - sign up in the box at the top right corner of the article or click here.

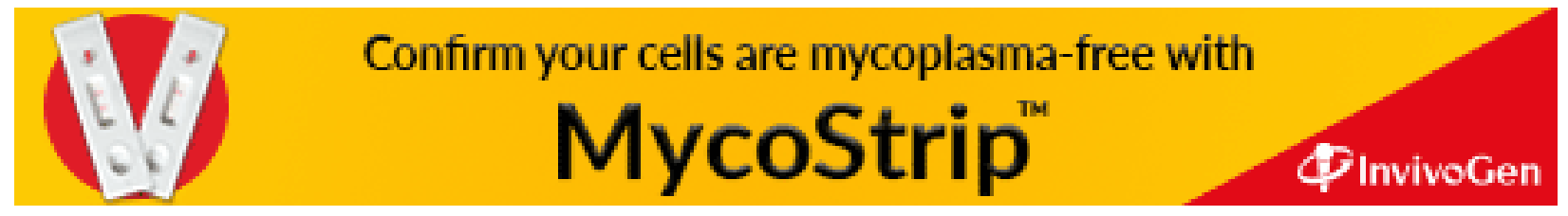

